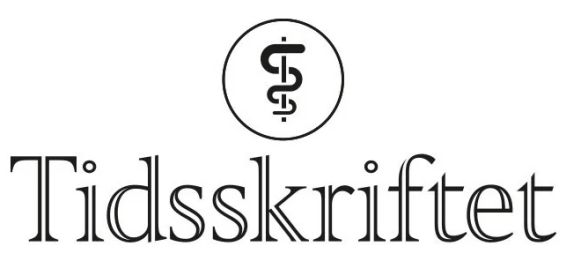

DEN NORSKE LEGEFORENING

\title{
Lungeembolisme ved covid-19
}

\author{
KORT KASUISTIKK
}

\section{ANDERS TVEITA}

andaun@vestreviken.no

Medisinsk avdeling

Bærum sykehus

og

K.G. Jebsen-senter for B-cellekreft

Oslo universitetssykehus

Anders Tveita er ph.d., lege i spesialisering og forsker.

Forfatteren har fylt ut ICMJE-skjemaet og oppgir ingen interessekonflikter.

\section{SIV HESTENES}

Avdeling for anestesi, intensiv, operasjon og akuttmottak

Bærum sykehus

Siv Hestenes er spesialist i anestesiologi og overlege.

Forfatteren har fylt ut ICMJE-skjemaet og oppgir ingen interessekonflikter.

\section{EIRIK ROBSAHM SPORASTØYL}

Medisinsk avdeling

Bærum sykehus

Eirik Robsahm Sporastøyl er lege i spesialisering.

Forfatteren har fylt ut ICMJE-skjemaet og oppgir ingen interessekonflikter.

\section{STIAN ALEKSANDER PETTERSEN}

Avdeling for bildediagnostikk

Bærum sykehus

Stian Aleksander Pettersen er lege i spesialisering ved Radiologisk seksjon. Forfatteren har fylt ut ICMJE-skjemaet og oppgir ingen interessekonflikter.

\section{BENTE LUND NEPLE}

Avdeling for bildediagnostikk

Bærum sykehus

Bente Lund Neple er spesialist i radiologi og medisinsk ansvarlig overlege ved Radiologisk seksjon. Forfatteren har fylt ut ICMJE-skjemaet og oppgir ingen interessekonflikter.

\section{MARIUS MYRSTAD}

Medisinsk avdeling

Bærum sykehus

Marius Myrstad er ph.d., spesialist i indremedisin og i geriatri og overlege.

Forfatteren har fylt ut ICMJE-skjemaet og oppgir ingen interessekonflikter. 
Arnljot Tveit er avdelingssjef og professor II.

Forfatteren har fylt ut ICMJE-skjemaet og oppgir ingen interessekonflikter.

\section{HEGE FRØEN}

Medisinsk avdeling

Bærum Sykehus

Hege Frøen er spesialist i indremedisin og i blodsykdommer og seksjonsoverlege ved Seksjon for blodsykdommer.

Forfatteren har fylt ut ICMJE-skjemaet og oppgir ingen interessekonflikter.

\section{JAN SVENDSEN}

Medisinsk avdeling

Bærum sykehus

Jan Svendsen er spesialist i indremedisin og i infeksjonssykdommer og overlege ved Seksjon for infeksjonsmedisin.

Forfatteren har fylt ut ICMJE-skjemaet og oppgir ingen interessekonflikter.

\section{ELSE JOHANNE RØNNING}

Medisinsk avdeling

Bærum sykehus

Else Johanne Rønning er spesialist i indremedisin og i infeksjonssykdommer og seksjonsoverlege ved Seksjon for infeksjonsmedisin.

Forfatteren har fylt ut ICMJE-skjemaet og oppgir ingen interessekonflikter.

\section{Vi beskriver her lungeembolisme hos tre pasienter i ulike faser av covid-19. Utvikling av lungeembolisme kan lett overses, fordi respirasjonssvikt og hypoksemi kan tilskrives sars-CoV-2-pneumoni.}

Bildet kompliseres av kraftige akuttfasereaksjoner og utbredt inflammasjon i lungene. Lungeembolisme forekommer også hos covid-19-pasienter som får tromboseprofylakse med lavmolekylært heparin, og smittevernhensyn bør ikke komme i veien for nødvendig bildediagnostikk.

\section{Pasient 1}

En mann i 7o-årene med diabetes type 2 ble innlagt etter tre dagers sykehistorie med feber og smerter i korsrygg og mage. Ved innkomst fant man respiratorisk alkalose og lett takypné. Røntgen thorax viste subtile pneumonisuspekte fortetninger basalt i høyre lunge. Sars-CoV-2 ble påvist i luftveissekret. Pasienten ble behandlet med $\mathrm{O}_{2}$-tilskudd $2 \mathrm{l} / \mathrm{min}$, men hadde vedvarende takypné. Han mottok enoksaparin $40 \mathrm{mg} \times 1$ som tromboseprofylakse. Dag 4 fant man økte bilaterale fortetninger på røntgen thorax, og innen dag 8 var det ytterligere progrediering.

Han hadde økende oksygenbehov fra dag 9, med behov for $10 \mathrm{l} / \mathrm{min}$ på reservoarmaske for å holde $\mathrm{SpO}_{2}>94 \%$. Han ble gradvis mer medtatt og sliten. Røntgen thorax dag 12 viste vesentlig uendret utbredelse av lungefortetninger. Grunnet manglende bedring i oksygenering og vedvarende sterkt forhøyet D-dimer til verdier > 10 mg/l FEU (figur 1 ) ble det dag 15 utført CT pulmonal angiografi. Denne avdekket bilaterale segmentale og 
subsegmentale lungeemboluser, i tillegg til utbredte infeksiøse fortetninger (figur 2a-b). Etter oppstart av antikoagulasjonsbehandling (enoksaparin $100 \mathrm{mg} \times 2$ ) ble oksygenbehovet gradvis redusert og allmenntilstanden raskt bedre.
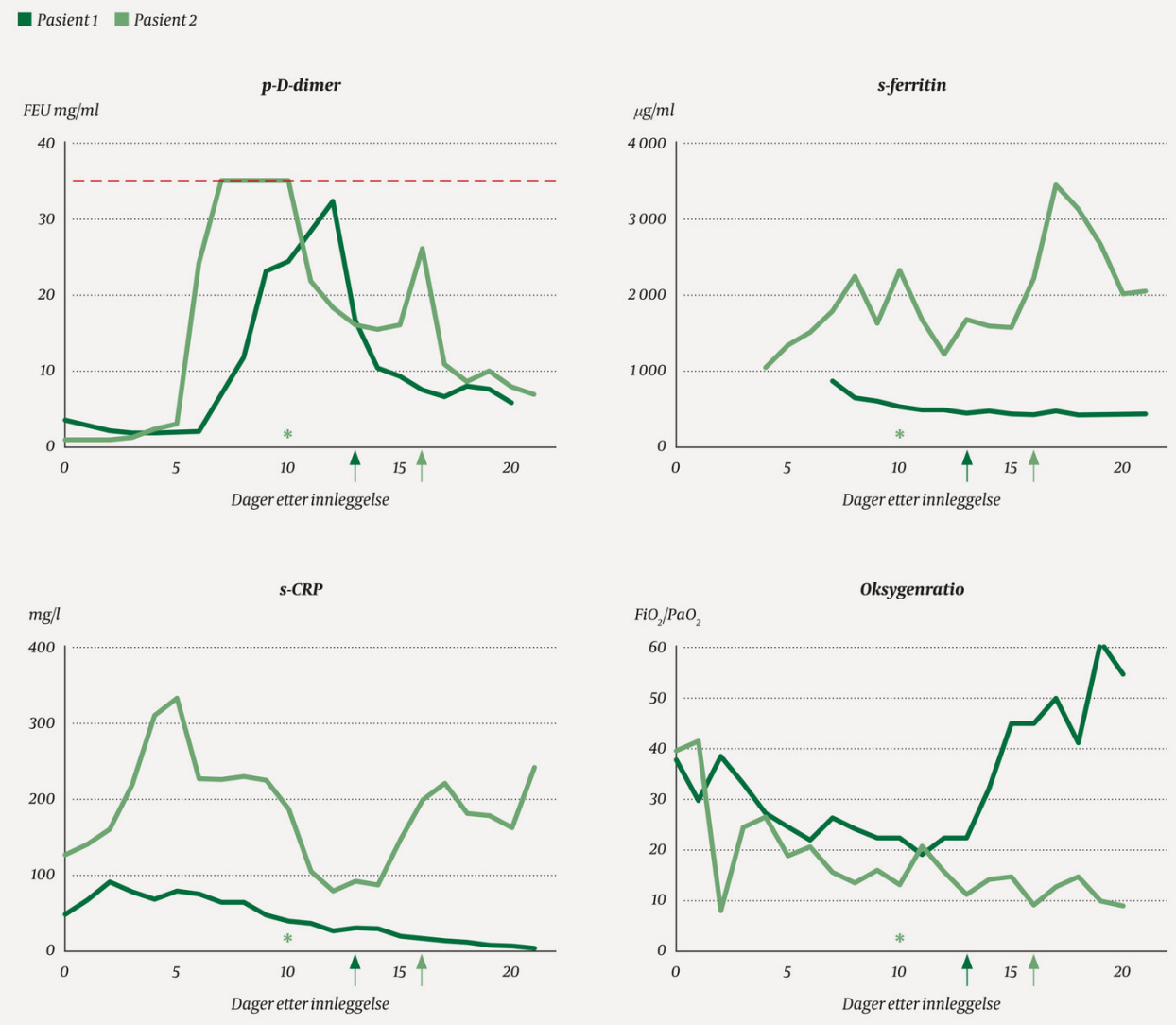

Figur 1 Tidslinje for nivå av D-dimer (fibrinogenekvivalente enheter, FEU) i plasma (p) og ferritin og C-reaktivt protein (CRP) i serum (s) hos pasient 1 og 2. X-akse angir antall dager etter innleggelse. Stiplet linje indikerer D-dimerverdier $>35,2 \mathrm{mg} / \mathrm{l} \mathrm{FEU,} \mathrm{hvor} \mathrm{videre}$ fortynning for kvantitering ikke ble utført. Det var betydelig dynamikk i D-dimer underveis i forløpet hos begge pasienter, med stigning til tosifrede verdier forut for CT-angiografi med påvisning av lungeemboluser (piler). ${ }^{*}$ indikerer tidspunkt for oppstart av immunmodulerende behandling (anakinra) hos pasient 2. Dette ble forsøkt på grunn av forutgående sterkt forhøyet ferritin og vedvarende høy D-dimer. Raskt fall i inflammasjonsparametrene ble observert etter oppstart, men uten vesentlig bedring i klinisk tilstand. Nederste panel viser oksygenratio, som uttrykk for oksygeneringsbehov gjennom sykdomsforløpet. Ratio reflekterer forholdstall mellom arterielt oksygentrykk $\left(\mathrm{PaO}_{2}\right)$ og fraksjon av inspirert oksygen $\left(\mathrm{FiO}_{2}\right)$. For pasient 1 er $\mathrm{PaO}_{2}$ estimert fra oksygenmetning målt ved pulsoksymetri ved bruk av omregningstabell. 


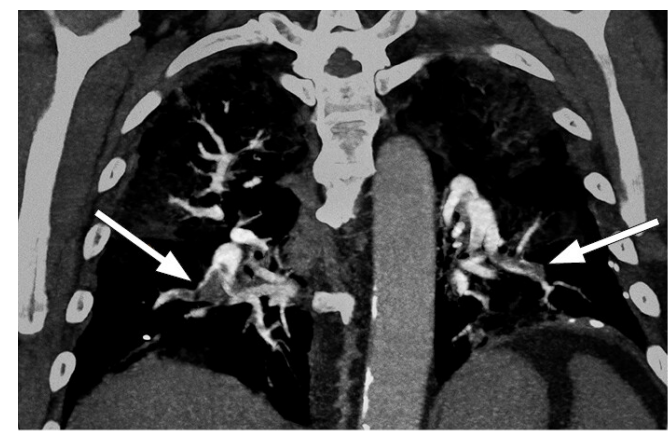

a

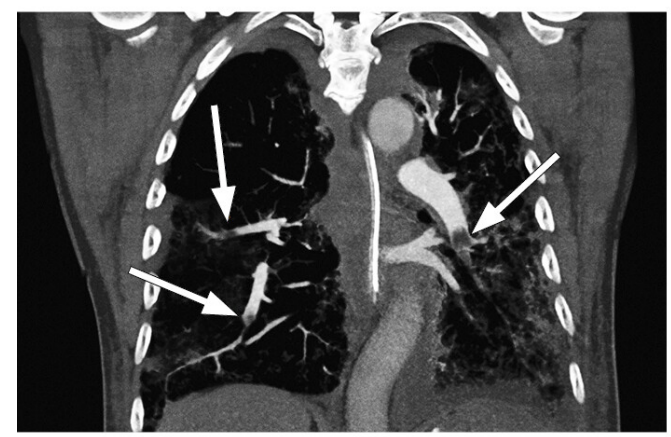

C

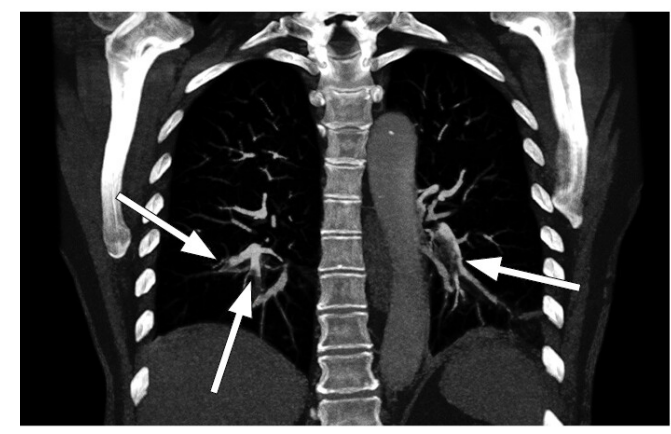

e

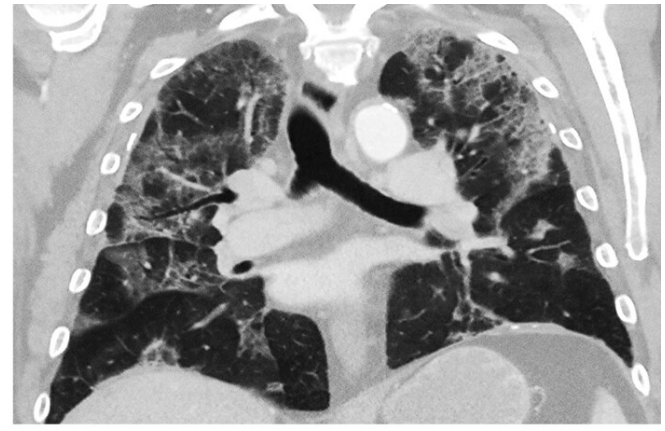

b

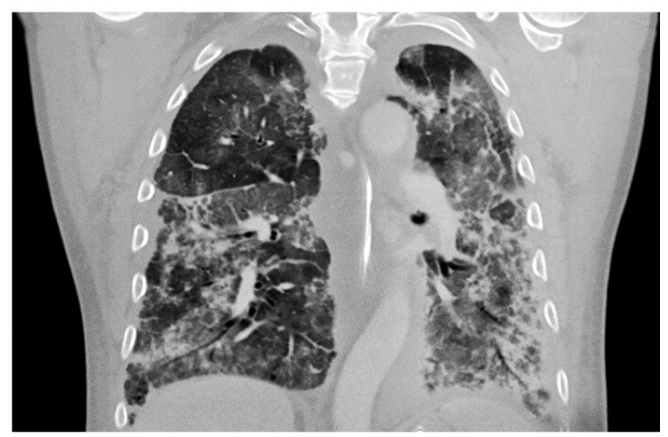

d

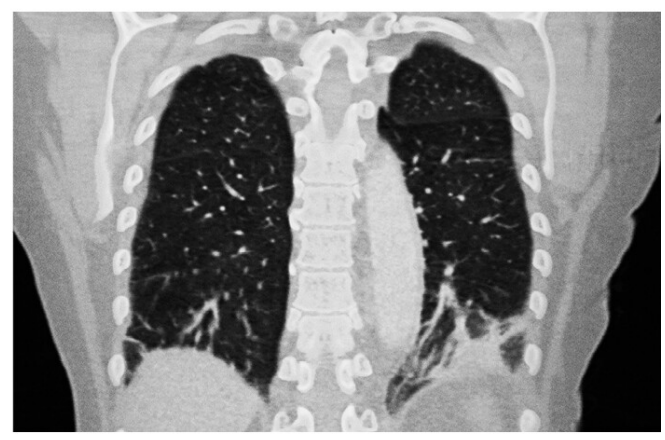

f

Figur 2 CT pulmonal angiografi med koronale MIP-rekonstruksjoner (maksimal intensitetsprojeksjon). Bildene viser lungeemboluser i pulmonalarterier til underlappene hos alle tre pasientene (a, c, e, piler). Pasient 1 (a, b) og 2 (c, d) hadde også bilaterale lungefortetninger med infeksiøst preg og hovedsakelig perifer distribusjon som fremkommer bedre i lungevindu (b, d). Hos pasient 3 (e, f) sees avrundet konsolidering med bred base mot pleura basalt i venstre underlapp, best forenlig med lungeinfarkt (f). Mattglassfortetninger rundt infarktet, ellers klare lunger.

\section{Pasient 2}

En tidligere frisk mann i slutten av 70-årene ble innlagt etter tre dagers sykehistorie med høy feber, tørrhoste og redusert allmenntilstand. Han hadde ikke dyspné, men hypoksemi med $\mathrm{SpO}_{2} 90 \%$ på romluft. Røntgen thorax ved innkomst viste normale forhold. Sars-CoV-2 ble påvist i luftveissekret. Han fikk enoksaparin $40 \mathrm{mg} \times 1$ som tromboseprofylakse. Ved ny røntgen thorax-undersøkelse dag 1 var det tilkommet bilaterale fortetninger. Dag 2 var han mer medtatt og hadde høyere oksygenbehov. Takypné oppstod dag 3, og røntgen viste progrediering av lungefortetninger. Han ble overflyttet til intensivavdeling og intubert.

Med bakgrunn i rapporter om økt forekomst av venøse tromboemboliske hendelser hos intensivpasienter med covid-19 valgte vi å øke profylaksedosen av enoksaparin til $40 \mathrm{mg} \times$ 2. Dag 7 steg D-dimerverdiene fra 2,8 til $24 \mathrm{mg} / \mathrm{l} \mathrm{FEU}$. Ferritinnivået var $>2000 \mu \mathrm{g} / \mathrm{ml}$, og man startet behandling med interleukin-1-reseptorantagonist (anakinra) dag 10. Fram til dag 13 så man radiologisk progrediering av lungefortetninger, mens D-dimerverdien falt etter oppstart av anakinra (figur 1). Grunnet ny D-dimerstigning fra 16 mg/l FEU til 26 mg/l 
FEU ble det dag 16 utført CT pulmonal angiografi. Man fant da bilaterale perifere lungeemboluser og utbredte fortetninger i alle lapper (figur 2c-d). Det ble startet antikoagulasjonsbehandling (enoksaparin $100 \mathrm{mg} \times 2$ ), men etter et langvarig forløp med stasjonær alvorlig lungesvikt døde pasienten dag 22.

\section{Pasient 3}

En tidligere frisk kvinne i 7o-årene gjennomgikk en ukes sykdom med lett tørrhoste og øvre luftveissymptomer. Det ble påvist sars-CoV-2 i luftveissekret etter to dager. Etter en to ukers periode uten symptomer tilkom det på ny tørrhoste, og pasienten ble innlagt dag 23 dager etter symptomdebut med aktivitetsdyspné og takypné. Det forelå ved innkomst respiratorisk alkalose, og D-dimerverdien var 1,9 mg/l FEU. Røntgen thorax viste normale funn. Det ble utført CT pulmonal angiografi, som avdekket bilaterale segmentale og subsegmentale lungeemboluser med affeksjon av alle lungelapper, uten funn av infeksjonssuspekte fortetninger (figur ze-f). Hun fikk peroral antikoagulasjonsbehandling (apiksaban $10 \mathrm{mg} \times 2$ ) og ble utskrevet da hun var i bedring.

\section{Diskusjon}

Kasuistikkene illustrerer lungeembolisme som medvirkende årsak til hypoksemi ved sarsCoV-2-infeksjon i ulike faser av sykdommen. Det er vanskelig å tidfeste nøyaktig når i forløpet denne komplikasjonen oppstod. For pasient 1 og 2 ble høye D-dimerverdier først tilskrevet kraftig, infeksjonsutløst akuttfaserespons (figur 1). Ettersom pasientene ble behandlet med lavmolekylært heparin under hele innleggelsen, ble mistanke om lungeembolisme først fattet senere i forløpet. Høye D-dimerverdier (>1,o mg/l FEU) ved innkomst er i flere studier rapportert å være assosiert med $ø \mathrm{kt}$ risiko for død ved covid-19 (1-3), men årsakssammenhengen er sannsynligvis multifaktoriell.

Hos pasient 2 observerte vi underveis i forløpet en kraftig stigning i serumnivåer av Creaktivt protein (CRP) og ferritin (figur 1). Alvorlig koronavirussykdom er rapportert å være assosiert med utvikling av en hyperinflammatorisk tilstand (cytokinstorm) som ledd i den immunologiske responsen mot viruset (4), og man har spekulert i om immunmodulerende behandling her kan ha en plass. Grunnet persisterende, alvorlig lungesvikt valgte vi derfor å fors øke immunmodulerende behandling med anakinra. Etter oppstart observerte vi raskt fallende nivåer av D-dimer, CRP og ferritin (figur 1), men ingen tegn til vesentlig klinisk bedring. Dette, sammenholdt med ny stigning i D-dimernivå, gav mistanke om lungeembolisme.

Covid-19 medfører hos mange et langvarig sykdomsforløp med høy feber, redusert allmenntilstand og lungepåvirkning, som alle bidrar til immobilisering. Intensivbehandling representerer i seg selv en vesentlig risikofaktor for tromboembolisk sykdom. Akutte infeksjonstilstander er assosiert med en betydelig, men forbigående økt risiko for venøse tromboemboliske hendelser (5). Kunnskap om patofysiologien ved covid19-assosiert tromboembolisk sykdom er fortsatt begrenset. Både virusinfeksjonen i seg selv og ledsagende antivirale immunresponser medfører risiko for kraftig aktivering av koagulasjonssystemet som følge av endotelskade, plateaktivering og frigjøring av potente proinflammatoriske cytokiner (므). Man har også mistenkt at endotelskade kan gi kraftig komplementaktivering og derved utløse en trombotisk mikroangiopati liknende den man ser ved atypisk hemolytisk-uremisk syndrom (7.). Antagelig skyldes den høye forekomsten av lungeembolisme ved covid-19 en kombinasjon av inflammasjonsmediert skade i affisert lungevev (3) og systemisk hyperkoagulabilitet.

I flere publikasjoner har man rapportert en påfallende høy forekomst av lungeembolisme hos covid-19-pasienter. Tilstanden er påvist hos 20-30 \% av pasientene der CT pulmonal angiografi har blitt utført på klinisk indikasjon (ㅇ-11). Biokjemiske og funksjonelle tegn på 
hyperkoagulabilitet er beskrevet hos alvorlig syke covid-19-pasienter og synes assosiert med dårlig prognose $(\underline{1}, \underline{2}, \underline{8}, \underline{12}, \underline{13})$.

Blant 184 nederlandske intensivpasienter fant man CT-/ultralyd-verifisert venøs tromboembolisk hendelse hos $27 \%$, hvorav $81 \%$ (25 pasienter) hadde lungeembolisme (ㅁ). Dyp venetrombose (DVT) ble påvist hos én pasient. Økte globale koagulasjonsparametere (INR, aktivert partiell tromboplastintid) predikerte forekomst av tromboemboliske komplikasjoner. Dette peker i retning av koagulopati som et bidrag til utvikling av lungeembolisme ved covid-19 ( $\underline{8})$. Det er verdt å merke seg at pasientene mottok tromboseprofylakse med lavmolekylært heparin. Doseringen var imidlertid forskjellig på de ulike sykehusene som deltok i studien, og det angis i artikkelen at dosene økte over tid. Ved ett av sentrene ble profylaksedosen i løpet av observasjonsperioden doblet til to daglige doseringer, og forfatterne argumenterer på basis av den slående høye forekomsten av lungeembolisme for at slik praksis må vurderes hos intensivpasienter med covid-19 ( $\underline{8}$ ).

I den nederlandske studien ble bildediagnostikk kun utført ved klinisk mistanke, og den totale forekomsten av tromboembolisk sykdom kan derfor være enda høyere (ㅁ). Hos 7 av 25 pasienter med lungeembolisme fant man kun subsegmentale emboluser. De kliniske konsekvensene av slike perifere tromber er trolig variable og avhengige av omfanget av den infeksjonsutløste parenkymskaden som foreligger.

Tilbakemeldinger til oss fra infeksjons- og intensivmedisinske miljøer i Norge er at man også her har observert en påfallende høy insidens av tromboemboliske komplikasjoner hos covid-19-pasienter, til tross for bruk av standard profylaksedoser med lavmolekylært heparin (ved vårt sykehus i form av enoksaparin $40 \mathrm{mg} \times 1$ ). Med bakgrunn i dette og egne erfaringer har vi derfor ved vår avdeling inntil videre valgt å benytte økt profylaksedose enoksaparin $(40 \mathrm{mg} \times 2)$ hos en del av disse pasientene. Systematiske studier av forekomst av dyp venetrombose og lungeembolisme vil være av stor verdi for å avdekke omfanget av slik sykdom hos hospitaliserte covid-19-pasienter og for å klarlegge underliggende patofysiologi.

Ved vårt sykehus har bruk av CT-undersøkelser i rutinediagnostikk ved covid-19 vært sterkt begrenset, primært betinget i at inflammatoriske forandringer fremkommer tydelig ved vanlig røntgen thorax, men også av smittevernmessige hensyn. I lys av høy forekomst av lungeembolisme i denne pasientgruppen bør man vurdere mer utbredt bruk av CTangiografi hos pasienter med vedvarende høyt oksygenbehov og biokjemiske tegn på hyperinflammasjon samt ved svært høye D-dimerverdier eller vesentlig dynamikk i denne parameteren.

\section{Konklusjon}

Høy forekomst av tromboemboliske komplikasjoner ved covid-19 fordrer en særlig oppmerksomhet blant leger som håndterer denne pasientgruppen både i og utenfor sykehus. Effektiv forebygging og rask påvisning av eventuelle lungeemboluser vil sannsynligvis bidra til at flere pasienter blir vellykket behandlet. Undersøkelse med CT pulmonal angiografi bør derfor vurderes hos pasienter med alvorlig sykdom selv om de blir behandlet med lavmolekylært heparin.

Med begrenset forståelse av underliggende patofysiologi og fravær av resultater fra randomiserte kontrollerte studier er det vanskelig å utforme retningslinjer for tromboseprofylakse ved covid-19. Forekomst av blødningskomplikasjoner bør også kartlegges bedre. Hvorvidt det er indikasjon for å gi hele pasientgruppen eller bare grupper av pasienter som man tror har særlig høy risiko, forhøyet profylaksedose eller behandlingsdoser med lavmolekylært heparin, er ikke avklart. I påvente av resultater fra systematiske studier er det ønskelig med en praksis basert på konsensus og erfaringer fra ulike sentre nasjonalt og internasjonalt. 
Pasientene har gitt samtykke til at artikkelen blir publisert.

Artikkelen er fagfellevurdert.

\section{LITTERATUR}

1. Zhou F, Yu T, Du R et al. Clinical course and risk factors for mortality of adult inpatients with COVID-19 in Wuhan, China: a retrospective cohort study. Lancet 2020;395:1054-62. [PubMed] [CrossRef]

2. Tang N, Li D, Wang X et al. Abnormal coagulation parameters are associated with poor prognosis in patients with novel coronavirus pneumonia. J Thromb Haemost 2020; 18: 844-7. [PubMed][CrossRef]

3. Fogarty H, Townsend L, Ni Cheallaigh C et al. COVID-19 coagulopathy in Caucasian patients. Br J Haematol 2020; 189: bjh.16749. [PubMed][CrossRef]

4. Mehta P, McAuley DF, Brown M et al. COVID-19: consider cytokine storm syndromes and immunosuppression. Lancet 2020;395: 1033-4. [PubMed][CrossRef]

5. Smeeth L, Cook C, Thomas S et al. Risk of deep vein thrombosis and pulmonary embolism after acute infection in a community setting. Lancet 2006;367:1075-9. [PubMed][CrossRef]

6. Giannis D, Ziogas IA, Gianni P. Coagulation disorders in coronavirus infected patients: COVID-19, SARS-CoV-1, MERS-CoV and lessons from the past. J Clin Virol 2020; 127:104362. [PubMed][CrossRef]

7. Campbell CM, Kahwash R. Will complement inhibition be the new target in treating COVID-19 related systemic thrombosis? Circulation 2020;141: CIRCULATIONAHA.120.047419. [PubMed] [CrossRef]

8. Klok FA, Kruip MJHA, van der Meer NJM et al. Incidence of thrombotic complications in critically ill ICU patients with COVID-19. Thromb Res 2020; 191: Soo49-3848(20)30120-1. [PubMed][CrossRef]

9. Poissy J, Goutay J, Caplan M et al. Pulmonary embolism in COVID-19 patients: Awareness of an increased prevalence. Circulation 2020; 141: CIRCULATIONAHA.120.047430. [PubMed][CrossRef]

10. Leonard-Lorant I, Delabranche X, Severac F et al. Acute pulmonary embolism in COVID-19 patients on CT Angiography and relationship to d-dimer levels. Radiology 2020; 295: 201561. [PubMed] [CrossRef]

11. Grillet F, Behr J, Calame P et al. Acute pulmonary embolism associated with COVID-19 pneumonia detected by pulmonary CT angiography. Radiology 2020; 295: 201544. [PubMed][CrossRef]

12. Ranucci M, Ballotta A, Di Dedda U et al. The procoagulant pattern of patients with COVID-19 acute respiratory distress syndrome. J Thromb Haemost 2020; 18: jth.14854. [PubMed][CrossRef]

13. Panigada M, Bottino N, Tagliabue P et al. Hypercoagulability of COVID-19 patients in Intensive Care Unit. A Report of Thromboelastography Findings and other Parameters of Hemostasis. J Thromb Haemost 2020; 18: jth.14850. [PubMed][CrossRef]

Publisert: 6. mai 2020. Tidsskr Nor Legeforen. DOI: 10.4045/tidsskr.20.0366

Mottatt 23.4.2020, første revisjon innsendt 1.5.2020, godkjent 4.5.2020.

Publisert under åpen tilgang CC BY-ND. Lastet ned fra tidsskriftet.no 26. april 2023. 